УДК 81’243-021.131:004.89+165.59

DOI https://doi.org/10.32838/2663-6069/2019.4-2/08

Devitska A. I.

Uzhhorod National University

\title{
AR/VR/AI IN SECOND LANGUAGE ACQUISITION
}

The present study explores the ways of using Virtual and Augmented Reality applications in the process of second language acquisition. In the article the concept of the second language acquisition in a broad sense refers to the learning of a nonnative language after the first language (that is the native language) has been learned, either in a naturalistic setting or in a formal classroom setting. The paper has argued that the most interesting way of using Virtual Reality programs is to imitate the socio-cultural reality of the language being studied, allowing the students to become participants in linguistic, cultural, socio-cultural or communicative situations. The paper depicts various Artificial Intelligence tools that have a significant impact not only on audio and visual perception, but also provide interaction, that results in more effective second language and culture acquisition. The article also analyzes the virtual presence in an interactive immediate situation, which allows the user to feel the reality of both the moment and the environment. Emotional Intelligence within the study is perceived as a kind of social intelligence that involves the power to observe one's own and others' emotions, to discriminate among them, and to use the data to guide one's thinking and actions, whereas the scope of Emotional Intelligence includes the verbal and nonverbal appraisal and expression of emotion, the regulation of emotion within the self and others, and therefore the utilization of emotional content in problem-solving.

The review also observes possible ways to succeed in acquiring the second language by means of Virtual and Augmented Reality as well as to implement socio-cultural and linguistic competences in students' future professional and personal communicative situations.

Key words: Virtual Reality, Augmented Reality, Artificial Intelligence, Second Language Acquisition, Emotional Intelligence, Language Cognition.

Statement of a scientific problem and its significance. Modern learners now were born during the globalized digital technologies era. Actually, the way they gain knowledge is very much technology-based and oriented, compared to previous generations of learners. Obviously, they cannot be impressed by the appearance of something new in today's world market as they easily absorb and adopt technologies such as cloud technologies, powerful smartphones, iGadgets, high-speed wireless internet 4 and 5G, Virtual and Augmented Reality games, Artificial Intelligence applications as well as 3D printing. "Generation Z" (young people born between 1995 to 2015) and "Generation Alpha" (children born between 2011, now, and into 2025) [8, p. 48] definitely need both updated interactive and immersive educational techniques in order to satisfy their real needs and wants in terms of educational process.

Most of the students today are those who use all existing technologies and they make an integral part of youth lives. Besides, young learners are always in the flow of all kinds of audio and video clip information that is freely available. Nowadays they watch a video or listen to audio sources instead of reading a book, as well as it is popular now rather have virtual communication than the real one by means of social networks. Therefore, the era of unprecedented technological advancements has totally changed the students' reality into Virtual and Augmented. Thus, we may say, that gadgets and applications also influence language formation, as computer slang is obviously transferred in everyday life and promotes the formation of memes, as well as the vocabulary expansion, for example, $L O L$ ("laughing out loud"), IMHO ("in my humble opinion" or "in my honest opinion"), ASAP ("as soon as possible"), BTW ("by the way"), G2G ("got to go", which is mostly used in chat rooms), $G G$ ("good going" or "good game", mostly used in online games such as trivia, Counter-Strike, etc.), GJ ("good job" or "well done"), NT ("No Text", used on Internet forums), OOC ("out-of-character", used in role-playing games), $R L$ ("real life", used in application settings), NOYB ("none of your business"), etc. The current process of second language acquisition has been transformed recently and it requires now various immersive language learning techniques, which can engage the students (both children and adults) in a realistic, embodied, perception and action rich context.

Analysis of studies of this problem. Virtual Reality, Augmented Reality, Artificial Intelligence 
and its impact on second language acquisition have been studied by many linguists recently. The linguists emphasize the effectiveness of second language acquisition with the help of special platforms with simulated action videos and online computer-based virtual environments (K. Jeong, R. Hyeonjeong, M. Sugiura, Y. Sassa, K. Wakusawa, K. Horie, S. Sato, A. Gonzalez-Pardo, D. Camacho, M. Ibáñez, M. Blanca, J. J. García, S. Galán, D. Maroto, D. Morillo Chen). Besides, the researches Chao, Zhenhua, and Yao have defined 360-degree video streaming as a new generation of technology, which provides bigger acceptance or "immersiveness" compared to the standard, traditional video streams and thus can result in better second language perception and acquisition. M. Fischer, H. Martin, A. Zwaan study how representation is based on visual, spatial, auditory, and other modality-specific experiences from Virtual and Augmented Reality environment by means of cognitive psychology. The focus of current scholars is mainly on emotional intelligence as second language acquisition is emotionally driven (P. MacIntyre, S. MacKinnon, R. Clement, Y. Imai). However, little is known about the specifics of Virtual and Augmented Reality immersive contexts that contribute to the second language acquisition. The generalisability of much published research on this issue is rather problematic.

The purpose of the article is to study the ways and means of using Virtual and Augmented Reality applications in the process of second language acquisition as well as their impact on developing communicative skills, socio-cultural and cross-cultural competence in the process of acquiring a second language. The object of our investigation are updated applications, educational platforms and software of Virtual and Augmented Reality as well as Artificial Intelligence.

The presentation of the main material and the justification of the results of the study. Linguists are currently concerned with the XXI century system for second language acquisition. Nowadays, students show no interest in traditional classes, which appear to be boring for them. Moreover, they go home to immerse themselves in this unreal experience while playing games and it makes a big difference in being them interested in the subject. However, Virtual and Augmented Reality tools for second language acquisition are not always accessible to every student, since many do not have the resources or time to immerse themselves or use properly the software or applications.

The empirical nature of Virtual and Augmented Reality applications and software appears from three sources: immersion, interactivity and multi-touch feedback. From the linguistic point of view "immersion" is an approach in second language pedagogy (second language acquisition, natural approach), where academic subjects are taught exclusively in the target language [1, p. 540]. In terms of our research second language acquisition in a broad sense refers to the learning of a nonnative language after the first language (that is the native language) has been learned, either in a naturalistic setting or in a formal classroom setting [1, p.1034].

Naturally, the advantage of immersion is that it provides the sensation of the presence or the feeling that a person is indeed in the depicted world [3]. Interactivity is the ability to control events in modeling using those body movements that are in your own the queue initiates responses in the simulation. Another significant aspect and purpose of Virtual Reality is to replace the real world with the virtual one and allow the user to act, think, perform and behave as if they were in the real world.

Virtual Reality (VR) - immersion into a digital reality environment. This means you can be present in two places at once, and it is enjoyed by so many students around the world as they play Minecraft, the Second Life, etc. Students share knowledge inside their group and analyze it together, which develops better cooperation skills.

Artificial Intelligence (AI) is the theory and development of computer systems able to perform tasks that normally require human intelligence, such as visual perception, speech recognition, decision-making, as well as translation between languages. Google, Siri, Apple actually foresight hole in the education, as those technologies may replace the teachers.

Augmented Reality (AR) overlays virtual projects on the real-world environment, often by using the camera on a smartphone. Generally, it makes a feeling of staying in students' reality, but they do something to augment it and make it more realistic. Thus, the students add some virtual sense to their reality (for example, they are following a virtual fashion) and the process can be endless. Another significant aspect of immersive Virtual Reality is that it offers a versatile platform to simulate an immersive learning situation, enabling the linguists to have tight experimental management for stimulant delivery and student interaction with real and virtual environment.

CoSpaces application, for example, helps to create $\mathrm{AR}$ and VR in the class, which comprises the unity for education platform for creating a VR world for better work in high school. Tour Builder, for instance, enables students to create their own virtual world trip 
(it also can be used as a Google Earth system). Thus, one can insert his own tags, add some videos, including discussion points, as well as put essays. Such activities can be useful for developing speaking and listening skills in second language acquisition.

In the age of modern technology, the representatives of "Generation Z" and "Generation Alpha" feel strongly the responsibility to make sure that they will be successful in the future. Projecting and experiencing Virtual and Augmented Reality, Artificial Intelligence applications allows the learners to succeed in acquiring second language as well as to implement socio-cultural and linguistic competences in their future professional and personal communicative situations. Artificial intelligence software helps learners to adapt to the future, as well as to become good lifetime learners, the future inventors, space travelers, innovators in space construction, to properly use their imagination and creativity in acquiring the second language. Therefore, AI helps to creative thinking during the process of second language acquisition at no cost or failure, as one can reuse the application as many times as one wants.

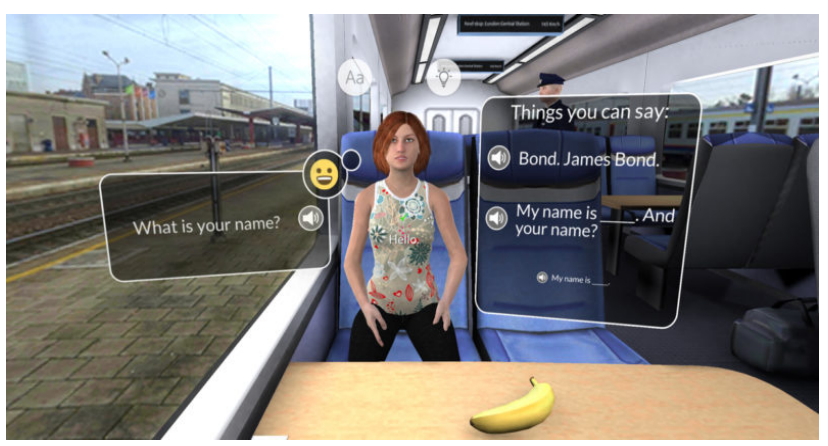

Pic. 1. Screenshot of VR platform Mondly

Mondly platform, launched VR and AR (experience by ATi studios), represents an immersive experience, as it takes the students' avatar through a series of exciting scenarios they would expect to experience as tourists in another country. Practicing communicative skills becomes more interesting, while chatting in a taxi cab, transactional speech at a restaurant and asking for help using public transport all that provides the real tourist experience.

Another specific feature of VR and AR applications is that they are user-friendly. For instance, Zappar helps to create even larger Augmented Reality, including zone tags, creating your own 3D projects. While acquiring the second language, the students also need to translate from a foreign language into their native. Thus, Google Translator allows students to translate a text from one language into another, by taking a picture or sample in a foreign language.
Afterward, it will appear on the screen in the correct language in reality, which is a version of AR. This application can be useful for bilingual students as well, as it helps to codeswitch more quickly by giving appropriate definitions. Younger students may be immersed into Cleverbook that enables to learn about different kinds of animals (appear on an interactive map), provides detailed information concerning geography, and finally, brings all objects to realistic environment.

Flipgrid $A R$ helps to acquire second language through conversational practice skills, allowing the students to voice their videos. Moreover, the application develops perceptive, visual and tactile experiences, concerned within the learner's integral illustration of ideas, objects, and action. This comprises all bodily sensation with perception of the input features, which, when used, would recruit neural regions accountable for perception and sensor (motor) actions. Thus, the cognitive abilities in the process of second language learning may be expanded by the following activities in Flipgrid AR:

- book reviews (printed out), including teasers on book videos; stories about the author (students make their own books); artwork or projects (can be made individually or within a group); key chains or Keepsakes (writing stories like Why I love my..., including audio files); making presents, bookmarks with QR code with audio comment recorded by a student;

- special cards (audio and video messages) to be scanned with Flipgrade app; classroom ARientation Guide (includes instructions explaining the rules for the group, how the things work in the class) - made by students to students;

- creating a Virtual Tour (telling stories about past events, practicing Past tenses); dedications and donations; various "How to" videos (3D printers are to be used); presentation for celebrations; yearbook (expressing and sharing students' ambitions, memories, achievements); gift tags with voiced video messages; Student Business card or Trading card;

- worksheets, digital presentations, teacher supporting video, translation support, audio recording, with sign language interpreter option included; certificates and positives; enhanced Newsletters; Edcamp Session Board (including $30 \mathrm{sec}$ video from teachers introducing the course); memory to treasure interview (Student interviewing a person special to him or her, which makes priceless memories);

- EntreprenAR (Selling and advertising different things, actions, events in order to raise money, attaching the video presenting the producer or entrepreneur 
as well as any project); pre-presentation Greeting (telling about the event, its agenda, testimonials), etc.

Remarkably, with the help of the QLONE application, the students can take pictures and turn them down to an AR object. The most interesting feature of the application is that students can create the artifacts on their own, which gives them an exceptional feeling of immersion into AR, problem-solving concepts, creating 3D artifacts. The importance of feeling being the creators themselves is unique as well as developing digitalized skills, kinesthetic experience, interaction, etc. Putting VR goggles or helmets on, students immerse themselves in the atmosphere of a simulator, game, training program together with the teacher, discussing the virtual reality process, they learn. Afterward, students can discuss and share their emotions and feelings they experienced while traveling in VR, AR.

In addition, it is important to argue, that the most interesting ways of using Virtual Reality programs is to imitate the socio-cultural reality of the language being studied, allowing the student to become a participant in the linguistic, cultural, socio-cultural or communicative situation. Virtual reality tools have a significant impact not only on audio and visual perception, but also provide interaction, which results in more effective second language and culture acquisition [7]. For example, students can practice communicative situations in particular topics, like "Travelling", "EU Countries", "English-speaking Countries", "Kinds of Transport", using VR/AR programs and education platfroms. Such virtual presence in an interactive immediate situation allows the user to feel the reality of both the moment and the environment, enables him to learn how to react, explain and perform his particular role in the group, etc.

Consequently, the process of acquiring the second language by means of Virtual and Augmented Reality appears to be much more efficient than the one in a traditional study room. As a result, modern educational establishments use Virtual and Augmented Reality tools to conduct lectures, practical classes, educational excursions, cross-linguistic studies during second language acquisition classes. Educational direction includes such applications of Virtual Reality tools as the organization of study tours, conducting lectures, seminars, practical and laboratory classes. Obviously, such Virtual and Augmented Reality technologies can also be used in the process of self-education while acquiring a second language. Besides, the use of Virtual Reality tools would change the methods of gaining knowledge and diversifying the learning process.
Particular attention should be paid to Emotional Intelligence and its competences in the process of second language acquisition. According to P. Salovey and J. Mayer "Emotional Intelligence" refers to a type of social intelligence that involves the ability to monitor one's own and others' emotions, to discriminate among them, and to use the information to guide one's thinking and actions [6, p. 187; 7]. The scope of Emotional Intelligence includes the verbal and nonverbal appraisal and expression of emotion, the regulation of emotion in the self and others, and the utilization of emotional content in problem-solving. Besides, both positive and negative emotions can affect students' replies and the possibility to negotiate their social and cultural environment.

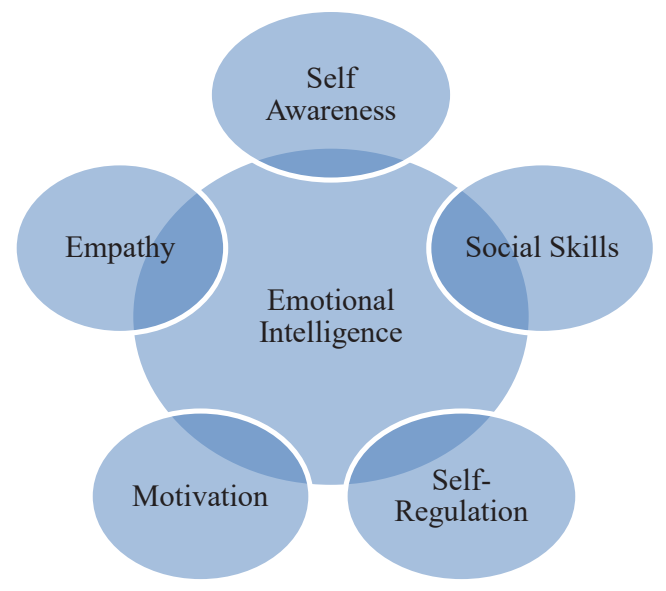

Pic. 2. Emotional intelligence and its competences

D. Goleman identified five skills and competencies that might be subsumed under the term "Emotional Intelligence": 1) Self-Awareness; 2) Self-Regulation; 3) Motivation; 4) Empathy; 5) Social Skills [2, p. 34]. In this regard, Self-Awareness is the ability to understand one's own emotions and their effect on others, whereas Self-Regulation is the ability to control or redirect disruptive impulses. Motivation is a passion to work with energy and persistence, as it means being driven, goal-oriented as well as optimistic $[4 ; 6]$. Finally, Empathy is the ability to understand the emotional needs of others and to treat them accordingly and Social Skill is proficiency, managing relationships, developing networks, and finding common ground. Due to D. Goleman, it is possible to develop one's own level of Emotional Intelligence by means of special training which helps to activate the brain's limbic system, and as a result, may govern our feelings and impulses [2, p. 35]. Cultivating emotions while acquiring a second language enables students to beat issues of demotivation resulted by fear or anger which can potentially endanger foreign language learning mastering. 
Conclusions. Virtual and Augmented Reality applications and environments have a high level of immersion and can be effective for second language acquisition. Artificial Intelligence provides effective learning and flexible platforms for designing learning environments that can vary in crucial characteristics, leading students to learning success. In future studies, we hope to include a more systematic analysis of Virtual and Augmented Reality software as well as Artificial Intelligence programs in order to understand the complex impact of highly immersive and interactive virtual environments on second language acquisition by bilinguals.

\section{References:}

1. Bussmann H. Routledge Dictionary of Language and Linguistics. London and New York: Routledge. 2006. $1335 \mathrm{p}$.

2. Goleman D. Leadership: The Power of Emotional Intelligence, Northhampton MA: More Than Sound. 2011. $116 \mathrm{p}$.

3. Legault J., Zhao J., Chi Y., Chen W., Klippel A., Li P. Immersive Virtual Reality as an Effective Tool for Second Language Vocabulary Learning. Languages. 2019, Volume 4. doi:10.3390/languages4010013

4. Mayer, J.D., Geher, G. Emotional intelligence and the identification of emotion. Intelligence. 1996. Volume 22. P. $89-113$.

5. Ruiqin M. Second Language Acquisition: An Introduction. International Encyclopedia of the Social \& Behavioral Sciences (Second Edition). 2015. P. 360-367.

6. Salovey P., Mayer J. D. Emotional intelligence. Imagination, Cognition, and Personality. 1990. Volume 9. P. 185-211. doi:0.2190/DUGG-P24E-52WK-6CDG

7. Shuttes N.S., Schuetplez E., Malouff J.M. Emotional intelligence and task performance. Imagination. Cognition and Personality. 2011. Volume 20. P. 347-354.

8. Strauss W, Howe N. Generations: The History of America's Future, 1584 to 2069. New York: William Morrow and Company Inc. 1991. 538 p.

\section{ДевіцЬКа А. І. ВІРТУАЛЬНА/ДОПОВНЕНА РЕАЛЬНІСТЬ ТА ШТУЧНИЙ ІНТЕЛЕКТ У ПРОЦЕСІ ВИВЧЕННЯ ДРУГОЇ МОВИ}

У статті проаналізовано методи використання програм/освітніх платформ віртуальної та доповненої реальності в проиесі оволодіння другою мовою. У статті поняття засвоєння другої мови використовується в ширшому розумінні та позначає процес вивчення нерідної мови після засвоєння рідної у природному або штучному середовищі. Водночас наголошується, що найдієвішим способом використання програм/освітніх платформ віртуальної та доповненої реальності є імітація сочіокультурної реальності мови, яка вивчається, що дозволяє студентам відчути себе учасниками мовних, культурних, соиіокультурних, комунікативних ситуацій чи подій.

Проаналізовано інструментарій освітніх платформ віртуальної та доповненої реальності, визначено його вилив не тільки на слухове, візуальне та інтерактивне сприйняття інформації, а також на ефективне засвоєння іншомовної культури. Схарактеризовано момент віртуальної присутності в безпосередній комунікативній ситуачії, зокрема, наголошено на важливості відчуття реальності миті та середовища, його контролю та взаємодії, щฺо дозволяє студентам опановувати реакиї та емочії, виконуючи певну роль.

Емоиійний інтелект у дослідженні розглядається як різновид соиіального інтелекту, який передбачає контроль над власними та чужими емочіями, ӥх розрізнення, правильне використання відповідно до думок та дій. Підкреслено, щзо інструментарій емоційного інтелекту включає вербальну та невербальну оцінку, вираження емоцій, їх відповідну регуляцію, а отже, використання емоційного компонента для вирішення проблем.

У статті також окреслено можливі способи застосування програм/освітніх платформ віртуальної та доповненої реальності для ефективного вивчення другої мови, реалізаиії соиіокультурних та мовних компетенцій у майбутніх професійних та особистих комунікативних ситуаціях студентів.

Ключові слова: віртуальна реальність, доповнена реальність, штучний інтелект, засвоєння другоі мови, емоційний інтелект, мовна когніція. 